ALONE TOGETHER 
This page intentionally left blank 


\title{
Alone Together
}

\author{
Poetics of the Passions in \\ Late Medieval Iberia
}

HENRY BERLIN

UNIVERSITY OF TORONTO PRESS

Toronto Buffalo London 
(C) University of Toronto Press 202I

Toronto Buffalo London

utorontopress.com

Printed in the U.S.A.

ISBN 978-I-4875-0967-5 (cloth)

ISBN 978-I-4875-0969-9 (EPUB)

ISBN 978-I-4875-0968-2 (PDF)

\section{Library and Archives Canada Cataloguing in Publication}

Title: Alone together : poetics of the passions in late-medieval Iberia / Henry Berlin.

Names: Berlin, Henry, author.

Series: Toronto Iberic ; 59.

Description: Series statement: Toronto Iberic ; 59 | Includes bibliographical references and index.

Identifiers: Canadiana (print) 2021020656X | Canadiana (ebook) 20210207302 |

ISBN 978I487509675 (hardcover) | ISBN 978I487509699 (EPUB) |

ISBN 9781487509682 (PDF)

Subjects: LCSH: Emotions in literature. | LCSH: Sentimentalism in literature. |

LCSH: Spanish literature - To I5Oo - History and criticism. | LCSH: Portuguese

literature - To 1500 - History and criticism.

Classification: LCC PQ6058 .B47 202I | DDC 861/.209353-dc23

This book has been published with the help of a grant from the Federation for the Humanities and Social Sciences, through the Awards to Scholarly Publications Program, using funds provided by the Social Sciences and Humanities Research Council of Canada.

University of Toronto Press acknowledges the financial assistance to its publishing program of the Canada Council for the Arts and the Ontario Arts Council, an agency of the Government of Ontario.

\section{Canada Council


"Love should be put into action!" screamed the old hermit.

Across the pond an echo

tried and tried to confirm it.

-Elizabeth Bishop, "Chemin de Fer" 
This page intentionally left blank 